\title{
GMR
}

\section{Genetic diversity among 16 genotypes of Coffea arabica in the Brazilian cerrado}

\author{
C.M.S. Machado ${ }^{1}$, N.S. Pimentel ${ }^{2}$, A. Golynsk ${ }^{2}$, A. Ferreira ${ }^{1}$, H.D. Vieira ${ }^{3}$ \\ and F.L. Partelli ${ }^{4}$ \\ ${ }^{1}$ Programa de Pós-Graduação em Genética e Melhoramento, \\ Universidade Federal do Espírito Santo, Campus Alegre, Alegre, ES, Brasil \\ ${ }^{2}$ Instituto Federal Goiano, Campus de Morrinhos, Morrinhos, GO, Brasil \\ ${ }^{3}$ Universidade Estadual do Norte Fluminense Darcy Ribeiro, \\ Campos dos Goytacazes, RJ, Brasil \\ ${ }^{4}$ Universidade Federal do Espírito Santo, Campus São Mateus, \\ São Mateus, ES, Brasil \\ Corresponding author: C.M.S. Machado \\ E-mail: cyntiameiry@gmail.com \\ Genet. Mol. Res. 16 (3): gmr16039794 \\ Received August 11, 2017 \\ Accepted August 21, 2017 \\ Published September 21, 2017 \\ DOI http://dx.doi.org/10.4238/gmr16039794 \\ Copyright (C) 2017 The Authors. This is an open-access article distributed under the terms of \\ the Creative Commons Attribution ShareAlike (CC BY-SA) 4.0 License.
}

\begin{abstract}
For the selection of coffee plants that have favorable characteristics, it is necessary to evaluate variables related to production. Knowledge of the genetic divergence of arabica coffee is of extreme importance, as this knowledge can be associated with plant breeding programs in order to combine genetic divergence with good productive performance. The objective of this study was to evaluate the genetic divergence among 16 genotypes of Coffea arabica with the purpose of identifying the most dissimilar genotypes for the establishment of breeding programs and adaptation to the Brazilian cerrado. The genetic divergence was evaluated using multivariate procedures, the analysis of the average grouping unweighted pair group method with arithmetic mean (UPGMA) and main components in 2013 and 2014. Eight characters were evaluated in an experiment conducted in Morrinhos,
\end{abstract}

Genetics and Molecular Research 16 (3): gmr16039794 
Goiás. The presence of genetic divergence among the 16 C. arabica genotypes under cerrado conditions was recorded. The formation of UPGMA groups for the evaluated characteristics was pertinent due to the number of genotypes. The first three major components accounted for $81.77 \%$ of the total variance. The genotype H-419-3-4-4-13(C-241) of low size was the most divergent, followed by Catucaí 2 SL and Catiguá MG2, according to the main components.

Key words: Coffeea arabica; Coffee breeding; Multivariate analysis; UPGMA

\section{INTRODUCTION}

The genus Coffea comprises more than 100 species (Davis et al., 2011). In Brazil, the two most economically important species, Coffea arabica and Coffea canephora, are cultivated simultaneously.

Coffee cultivation is an important source of income and is of great social and economic relevance for several production regions of the world. In 2016, the total area occupied by this crop was 2,223,464.1 ha, of which $79.9 \%$ of this area was occupied by C. arabica (CONAB, 2017).

The production of C. arabica species is present in all Brazilian regions. Notably, coffee production is notable due to the use of family labor, which mostly involves low technology. Such practices have influenced both coffee production and final grain quality, potentially affecting not only producers but also the entire industrial and final consumer market (Martins et al., 2016).

With the advent of climatic changes occurring in Brazil, areas of the Brazilian cerrado could be suitable for planting coffee crops in the near future. For this, the use of adapted genotypes or obtained varieties adapted to the edaphoclimatic conditions of the cerrado is required.

The availability of populations with genetic diversity and combining ability is critical for the success of the genetic improvement of coffee. The main limitations to obtaining segregant populations are the limited genetic variation and low recombination capacity due to repeated self-fertilization processes (Rodrigues et al., 2016). Thus, research to obtain superior genotypes and information on the agronomic superiority and genetic diversity that allow the combination and identification of the genetic set, as well as the evaluation of the viability of the crosses, has become a widely used tool for Genetic improvement (Rodrigues et al, 2016).

In addition to the difficulty in obtaining genetic progress in productivity, $C$. arabica has a long juvenile period and a biennial production, and as a perennial plant, several years are necessary to carry out the selection of new genotypes (Sera, 2001). Considering all these difficulties of the genetic improvement of coffee, it is of fundamental importance to use auxiliary characteristics in the selection processes that directly or indirectly increase grain yield (Petek et al., 2008). Thus, the search for satisfactory morphoagronomic characteristics in coffee begins with the manipulation of plant genetic resources (variability and genetic diversity), which constitutes the starting point of any plant breeding program.

The knowledge and study of the genetic divergence of a species tend to provide parameters that are of great value in the selection of parents that, when crossed, will allow greater heterotic effects in the progeny, increasing the chances of obtaining superior genotypes in segregating generations (Alvares et al., 2012).

The study of genetic diversity through multivariate techniques is of fundamental

Genetics and Molecular Research 16 (3): gmr16039794 
importance for the planning of breeding programs and the definition of future study strategies (Guedes et al., 2013). Thus, clustering techniques and principal component analyses can help guide the selection of genotypes that are better suited to a growing region.

In genetic breeding, studies on gain prediction by selection strategy provide a more efficient orientation to breeding programs and the choices of alternatives and more effective techniques based on scientific evidence (Oliveira et al., 2011).

Because of the presented context and the absence of studies on genetic diversity involving morphoagronomic characteristics based on multivariate analyses for coffee in the cerrado, this study aimed to evaluate the genetic diversity of 16 genotypes of $C$. arabica in the Brazilian cerrado.

\section{MATERIAL AND METHODS}

This experiment was conducted at the Goiano Federal Institute of Education, Science and Technology, Campus Morrinhos, Goiás, which is located southeast of the capital of the State of Goiás, from $17^{\circ} 30^{\prime} 20^{\prime \prime} \mathrm{S}$ to $18^{\circ} 05^{\prime} 40^{\prime \prime S}$ and from $48^{\circ} 41^{\prime} 08^{\prime \prime} \mathrm{W}$ to $49^{\circ} 27^{\prime} 34^{\prime \prime} \mathrm{W}$, at 750 $\mathrm{m}$ in altitude. The region has mild (tropical humid) climate and has flat topography and an undulating relief, with an average annual temperature of $20^{\circ} \mathrm{C}$. The seeds of the different genetic materials of $C$. arabica $\mathrm{L}$. used in this study were made available by EPAMIG, and the seedlings were grown in Morrinhos, Goiás. Planting was carried out on May 13, 2011 at a spacing of $3.5 \times 1 \mathrm{~m}$, regarding distance between lines and plants, respectively.

The experiment was established in four randomized blocks. Plot treatments consisted of five plants of the different genotypes Catiguá MG2, Mundo Novo IAC 379/19, Mundo Novo IAC 376/4, Mundo Novo Machado, Catuaí vermelho IAC 99, Catucaí 2 SL, Acaiá cerrado MG 1474, Catuaí amarelo IAC 62, Araponga MG1, H-518-3-6-462-M, H-419-3-3-716-11, H-419-3-4-4-13(C-241) Porte baixo, H-419-3-4-4-13(C-241) Bordadura, H-516-2-1-17-1, H-516-2-1-1-12-1, and H-419-6-2-4-2-2.

Genotypes were evaluated in 2013 and 2014. Characteristics evaluated in 2013 included the length of the orthotropic branch (LOB), the number of nodes of the orthotropic branch (NNO), the length of the plagiotropic branch (LPB), the number of nodes of the plagiotropic branch (NNP), and productivity (P). Later, in the year 2014, the characteristics consisted of specific leaf area (SLA), the diameter of the crown base (DCB), the length of the orthotropic branch (LOB), the diameter of the orthotropic branch (DOB), root volume $\left(\mathrm{mm}^{3}\right)(\mathrm{RV})$, root surface area $\left(\mathrm{mm}^{2} / \mathrm{cm}^{3}\right)(\mathrm{RSA})$, root weighted diameter $(\mathrm{mm})(\mathrm{RWD})$, and productivity $(\mathrm{P})$.

The characteristics were evaluated every other week in the period from January 8 to December 19, 2013. The LOB was measured with a graduated ruler from the base of the stem to the apex. The LPB was obtained by the distance between the insertions of the plagiotropic branches and the orthotropic branch and its apical meristem. The NNO was determined by the direct count on the branch, and the NNP was determined by the direct count on the branch.

In 2014, to evaluate the leaf area (LA), 20 leaves of the middle third of the plant were collected. Afterward, with the aid of a leaf area meter, the SLA was calculated. The DCB and the LOB were evaluated with the aid of a graduated scale. The DCB was measured at the largest base of the plant crown and the LOB from the base of the plant to the apex. The DOB was obtained using a digital calliper.

Root-related characteristics such as RV $\left(\mathrm{mm}^{3}\right), \operatorname{RSA}\left(\mathrm{mm}^{2} / \mathrm{cm}^{3}\right)$ and $\mathrm{RWD}(\mathrm{mm})$ were determined from soil monoliths involving roots collected at distances that varied with the

Genetics and Molecular Research 16 (3): gmr16039794 
diameter of the crown of the evaluated genotype at a depth ranging from 0 to $0.20 \mathrm{~m}$ for the four cardinal points of the plant. One plant per plot in each block was evaluated.

The collected samples were stored in plastic bags for the separation of roots. Washing was carried out under running water using a 30 -mesh sieve. The roots collected by the 30 mesh sieve were transferred to another of 60-mesh sieve and again washed in running water (Partelli et al., 2006, 2014; Covre et al., 2015).

Washed roots were imaged with a Kodak EasyShare M530 digital camera and later analyzed using the SAFIRA - Fiber and Root Analysis System, developed by Embrapa Instrumentação Agropecuária, São Carlos, SP (Jorge and Rodrigues, 2008), for the quantification of root length (RL), RV, and RSA. For root system analysis, roots smaller than $1 \mathrm{~mm}$ in diameter were used, and the data were estimated per cubic centimeter of soil (Partelli et al., 2014; Covre et al., 2015).

Production was evaluated based on the harvest that was performed when $90 \%$ of the fruits presented cherry coloration. Fruits were collected manually into a canvas bag to avoid contact with the soil and then dried. After drying, samples composed of the fruits of the five plants of each plot were ground.

Variables analyzed in 2013, including LOB, NNO LPB, and NNP, were used to estimate genetic diversity from the matrix of mean Euclidean distances. The data were standardized as follows:

$$
d_{i i^{\prime}}=\sqrt{\frac{1}{n} \sum_{j}\left(x_{i j}-x_{i^{\prime} j}\right)^{2}}
$$

where $\mathrm{d}_{\mathrm{ii}}$ is the mean Euclidean distance between genotypes $\mathrm{i}$ and $\mathrm{i}$ '; $\mathrm{x}_{\mathrm{ij}}$ is the value attributed to the characteristic studied for the genotype; $\mathrm{x}_{\mathrm{ij}}$ is the value attributed to the trait studied for the $i^{\text {th }}$ genotype; and $n$ is the number of characteristics studied (in the experiment).

Using the Genes Computational Program (Cruz, 2013), we grouped the 16 genotypes of $C$. arabica using the UPGMA. The dendrogram of the tree was established by the genotypes with the greatest similarity, where the distance between genotype $\mathrm{k}$ and the group formed by genotypes $i$ and $j$ was given by the following equation:

$$
d_{(i j) k}=\frac{d_{i k}+d_{j k}}{2}
$$

The relative importance of the characteristics evaluated for the genetic divergence discrimination by the main components method was also verified. Specifically, variables with greater weight in the linear combination of the first main components are the most important from a statistical point of view.

The importance of two characters considering the variable load $\mathrm{k}$ in the $\mathrm{j}^{\text {th }}$ main component is given by the following equations:

$$
\text { load }=\frac{C_{k j}}{\sqrt{\lambda_{j}}}
$$

Genetics and Molecular Research 16 (3): gmr16039794 


$$
r_{k j}=\frac{\operatorname{Cov}\left(x_{k}, y_{j}\right)}{\sqrt{\left(x_{k}\right) V\left(Y_{J}\right)}}=\frac{\alpha_{1 J} r_{1 k}+\alpha_{2 J} r_{2 k}+\ldots+\alpha_{k J}+\ldots+\alpha_{p J} r_{p k}}{\sqrt{\lambda_{J}}} \text { (Equation 4) }
$$

where $r_{\mathrm{kj}}$ is the $\mathrm{k}^{\text {th }}$ element of the $\mathrm{j}^{\text {th }}$ eigenvector.

\section{RESULTS AND DISCUSSION}

Several techniques can be applied for multivariate assessments in the prediction of genetic divergence, such as principal component analysis, canonical variables, agglomerative methods, or clustering methods. The choice of the most appropriate method should be performed according to the desired precision, the ease of analysis and the way the data were obtained (Fonseca et al., 2006).

The UPGMA was efficient at grouping the genotypes, and cuts were performed in accordance with the Mojena (1977) method. The UPGMA allowed the formation of two distinct groups for the characteristic LOB, shown in Figure 1, and the genotypes that were part of the same group had genetic similarity between them.

The first group consisted of six genotypes, Catuaí vermelho IAC 99, Mundo Novo Machado, Catucaí 2 SL, Acaiá cerrado MG 1474, H-518-3-6-462-M, and H-419-3-4-413(C-241) Porte baixo, and the second group consisted of 10 genotypes, Catuaí amarelo IAC 62, H-419-3-3-7-16-11, Catiguá MG2, Araponga MG1, Mundo Novo IAC 376/4, H-516-2-11-7-1, H-419-6-2-4-2-2, Mundo Novo IAC 379/19, H-419-3-4-4-13(C-241) Porte baixo, and H-516-2-1-1-12-1.

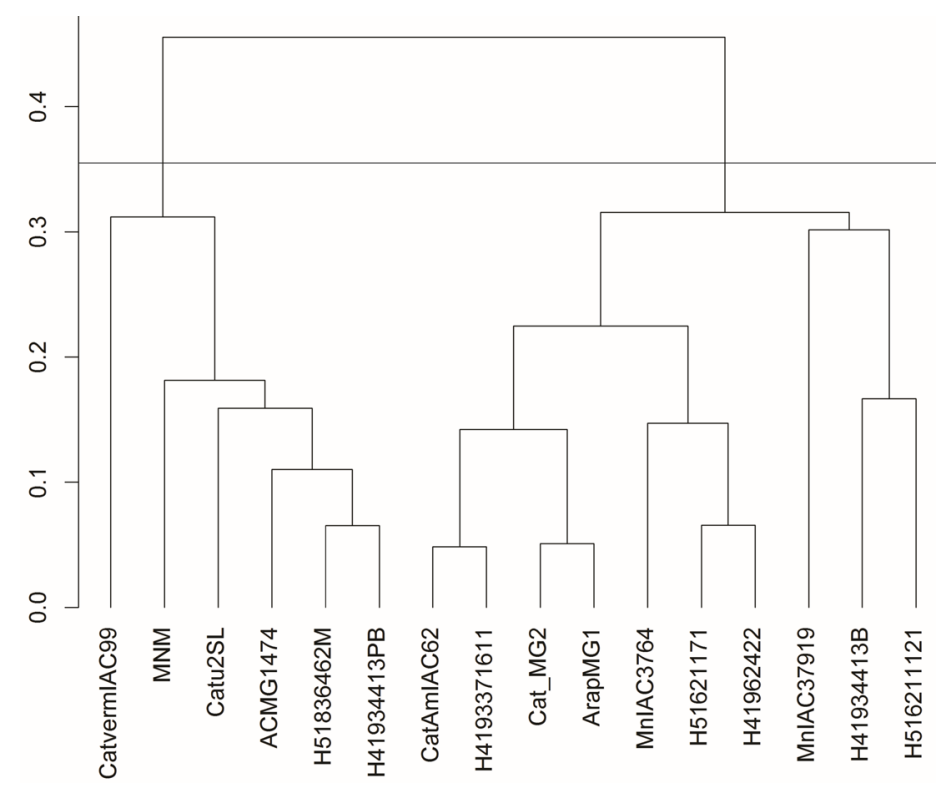

Figure 1. Dendrogram representative of genetic divergence among 16 genotypes of Coffea arabica, feature length of the orthotropic branch (LOB) obtained by the UPGMA method using the model Mojena in trials in Morrinhos - Goiás.

Genetics and Molecular Research 16 (3): gmr16039794 
Possibly, climatic effects on the genotypes were evident; thus, genotypes of tall plants such as the Mundo Novo Machado were grouped by the UPGMA (Figure 1) with genotypes having admittedly low size, such as Catuaí vermelho IAC 99 and Catucaí 2 SL. Another factor involves the cultivars of the Catuaí group originating from the artificial cross between Caturra and Mundo Novo (Botelho et al., 2010), in which different responses of genetic material to different environments prove what is known as genotype-environment interaction, which suggests that the phenotypes presented by the various genotypes are influenced by environmental conditions (Cucolotto et al., 2007).

The same grouping and cutting criteria of the variable NNO allowed the formation of two distinct groups, shown in Figure 2.

The first group was formed by genotype H-516-2-1-1-7-1, and the second group was formed by fifteen of the 16 evaluated genotypes: Catiguá MG2, Mundo Novo IAC 379/19, Mundo Novo IAC 376/4, Mundo Novo Machado, Catuaí vermelho IAC 99, Catucaí 2 SL, Acaiá cerrado MG 1474, Catuaí amarelo IAC 62, Araponga MG1, H-518-3-6-462-M, H-4193-3-7-16-11, H-419-3-4-4-13(C-241) Porte baixo, H-419-3-4-4-13(C-241) Bordadura, H-5162-1-1-12-1, and H-419-6-2-4-2-2.

It was observed that genotype H-516-2-1-1-7-1 was highly divergent from the others, as it formed an exclusive group and remained isolated from the other accessions in the dendrogram. Such genotypes may be promising for programs to improve $C$. arabica that target plants adapted to less dense planting plantations.

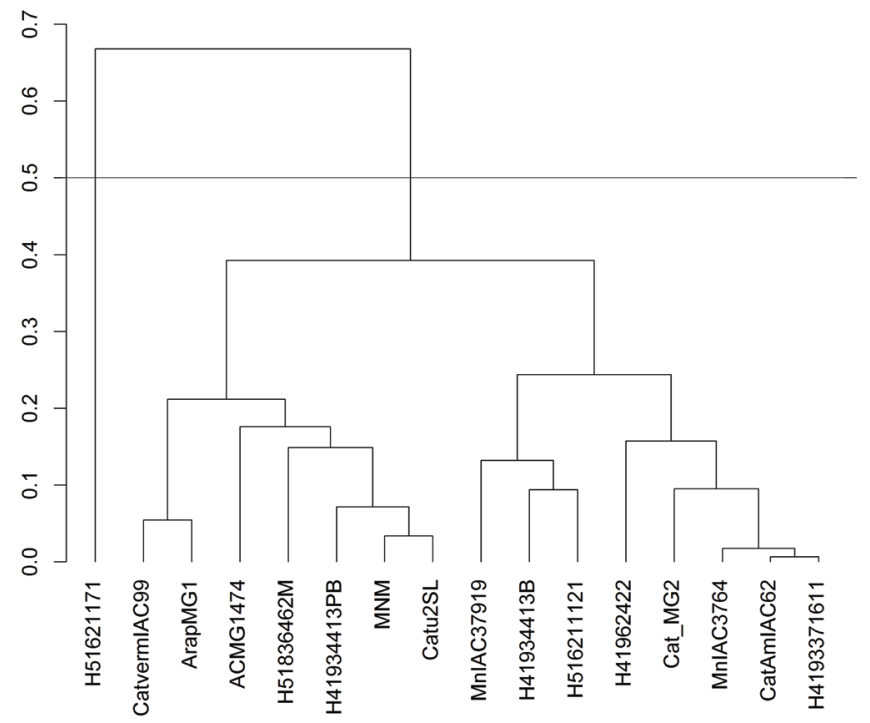

Figure 2. Group membership dendrogram feature representation for the number of nodes of the orthotropic branch (NNO) among 16 genotypes of Coffea arabica. The distances were calculated using dissimilarity matrices Mojena and grouped according to UPGMA method.

Using the magnitude of the genetic dissimilarity for the variable length of the plagiotropic branch as a criterion (Figure 3), we verified the formation of two distinct groups of individuals. Group 1 consisted of H-419-3-4-4-13(C-241) Porte baixo, H-518-3-6-462-M, Mundo Novo IAC 379/19, Catuaí amarelo IAC 62, and H- 3-3-7-16-11. Group 2 consisted of

Genetics and Molecular Research 16 (3): gmr16039794 
Catuaí vermelho IAC 99, H-516-2-1-1-12-1, Mundo Novo Machado, Catucaí 2 SL, Mundo Novo IAC 376/4, H-516-2-1-1-7-1, Acaiá cerrado MG 1474, H-419-6-2-4-2-2, H-419-3-4-413(C-241) Bordadura, Catiguá MG2, and Araponga MG1, corroborating the results of Silva et al., (2013), who assessed the genetic divergence in coffee accessions.

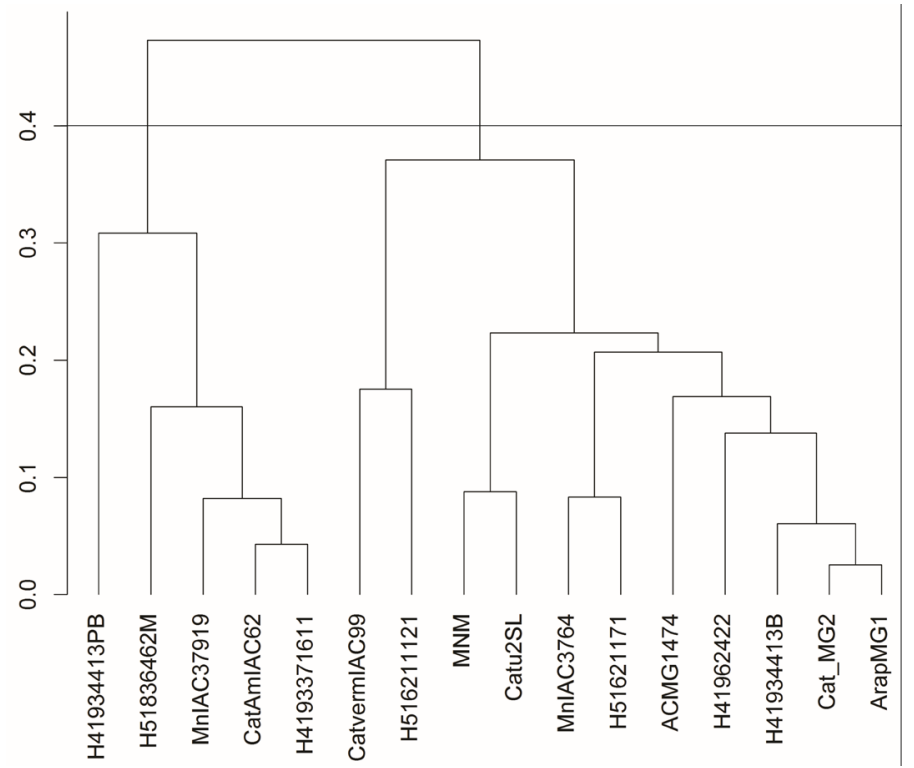

Figure 3. Dendrogram genetic similarity between 16 genotypes of Coffea arabica cultivars obtained from agronomic characters length of plagiotropic branch (LPB) using the UPGMA method. The dotted line indicates the cut-off point based on the calculated average similarity of $40 \%$.

The dendrogram obtained by the UPGMA (Figure 4) considering the cut in accordance with the Mojena (1977) method at 50\% of the maximum melting level for the variable NNP showed that the 16 genotypes were separated into two dissimilar groups: the first group comprised the genotype Catuaí vermelho IAC 99, and the second group comprised the other genotypes evaluated, Acaiá cerrado MG 1474, Catuaí amarelo IAC 62, H-419-3-4-413(C-241) Porte baixo, H-516-2-1-1-12-1, Mundo Novo IAC 376/4, Mundo Novo IAC 376/4, Catucaí 2 SL, Catiguá MG2, H-518-3-6-462-M, Araponga MG1, H-516-2-1-1-7-1, H-419-62-4-2-2, Mundo Novo IAC 379/19, Mundo Novo Machado, H-419-3-3-7-16-11, and H-4193-4-4-13(C-241) Bordadura.

The Catuaí red genotype IAC 99 was the most divergent genotype and should be used in genetic breeding programs, especially in the production of plants that are expected to produce higher yield. This genotype more strongly expressed the characteristic number of nodes of the productive (plagiotropic) branches and exhibited good correlation between NNP and productivity.

Evaluations of morphological characteristics are important for coffee breeding programs, as they aid the breeder in selecting and discarding early accessions (Teixeira et al., 2013).

The evaluations of the characteristics in 2014, which included SLA, DCB, LOB, DOB, RV, RSA, RWD, and P, can help in the selection and disposal of accessions.

Genetics and Molecular Research 16 (3): gmr16039794 


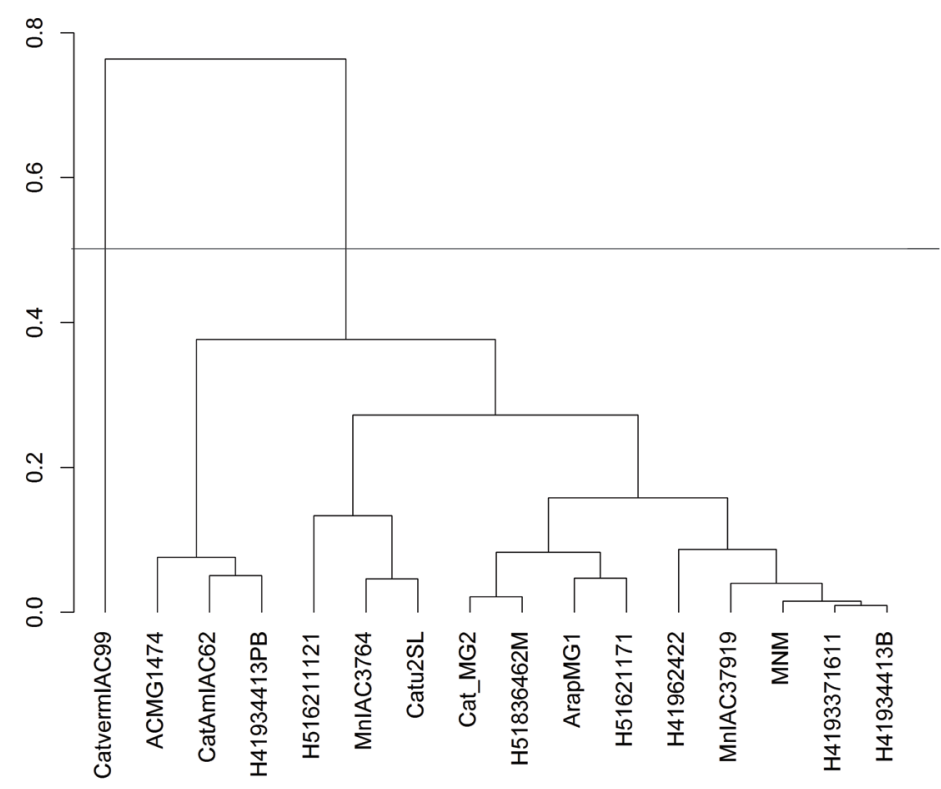

Figure 4. UPGMA hierarchical cluster analysis of the evaluated characteristic number of number of nodes of plagiotropic branch (NNP) by the UPGMA method of 16 genotypes of Coffea arabica.

Estimates of the eigenvalues and their corresponding individual and accumulated variances are presented in Table 1. The results show that the first three components are the most important in the discrimination between the C. arabica genotypes, explaining $81.77 \%$ of the total variance. In addition to allowing the study of genetic diversity, this result can be considered good, as a total variation greater than $80 \%$ obtained with two or three of the main components allows the analysis of groups of genotypes using dispersion plots (Cruz et al., 2012, 2014).

Table 1. Estimates of the eigenvalue variance, percentage of variance and accumulated variance of the main components, obtained from eight morphological characters of Coffea arabica, Morrinhos, Goiás.

\begin{tabular}{l|c|c|c}
\hline Component & Eigenvalue & Variance (\%) & Accumulated (\%) \\
\hline 1 & 2.9543 & 36.9288 & 36.9288 \\
\hline 2 & 2.5113 & 31.3920 & 68.3208 \\
\hline 3 & 1.0763 & 13.4538 & 81.7746 \\
\hline 4 & 0.6394 & 7.9928 & 89.7674 \\
\hline 5 & 0.5396 & 6.7455 & 96.5130 \\
\hline 6 & 0.1975 & 2.4688 & 98.9819 \\
\hline 8 & 0.0612 & 0.7661 & 99.7480 \\
\hline
\end{tabular}

The highest-weight variables in the first vector, which accounted for $36.9288 \%$ of the total variability, were (in decreasing order) LOB, SLA, DCB, and RV, followed by the others (Table 2). Specifically, as occurred between the values (positive), this main component effectively differentiated the groupings according to characteristics related to the vegetative size of the plants.

Genetics and Molecular Research 16 (3): gmr16039794 
The second vector [principal component 2 (CP2)] explained $31.3920 \%$ of the variability of the data, and the highest values were obtained with the specific area of the crown (mm), DCB, DOB, and RSA (Table 2).

The third main component (CP3) explained $13.4538 \%$ of the variability of the data, with higher values (positive and/or negative) based on the specific area of the crown, the DCB, RSA, and RWD (Table 2).

Based on the results, it is possible to observe that some of the variables are more important regarding the discrimination between $C$. arabica genotypes in the Brazilian cerrado. Future use of these research data could focus on greater efforts in the evaluation of the same variables, discarding the evaluation of the other variables that contributed little to the distinction of materials.

Table 2. Estimates of eigenvectors (principal components - CP) and respective weights of each variable for
their constitution.
\begin{tabular}{l|c|c|c|c|c|c|c|c|c}
\hline Variables & CP1 & CP2 & CP3 & CP4 & CP5 & CP6 & CP7 & CP8 \\
\hline SAC & 0.291 & 0.264 & 0.192 & 0.198 & 0.471 & 0.506 & 0.540 & 0.023 \\
\hline DBC & 0.279 & 0.366 & 0.517 & 0.461 & -0.290 & -0.271 & -0.160 & -0.354 \\
\hline LOB & 0.499 & -0.301 & -0.308 & -0.167 & 0.171 & 0.031 & -0.100 & -0.705 \\
\hline DOB & -0.187 & 0.712 & -0.038 & -0.543 & 0.019 & 0.212 & -0.240 & -0.243 \\
\hline RV & 0.697 & 0.107 & -0.001 & -0.409 & -0.332 & -0.128 & 0.115 & 0.443 \\
\hline RSA & 0.050 & 0.369 & -0.767 & 0.447 & -0.243 & 0.000 & 0.111 & 0.032 \\
\hline RWD & -0.169 & -0.197 & 0.103 & -0.942 & -0.701 & 0.471 & 0.366 & -0.259 \\
\hline P & -0.194 & 0.112 & -0.019 & -0.220 & 0.063 & -0.622 & 0.675 & -0.232 \\
\hline SPecif & & & & & & & & \\
\hline
\end{tabular}

Specific area crown $(\mathrm{mm})=\mathrm{SAS}$, diameter of the crown base $=\mathrm{DCB}$, length of the orthotropic branch $=\mathrm{LOB}$, diameter of the orthotropic branch $=\mathrm{DOB}$, root volume $\left(\mathrm{mm}^{3}\right)=\mathrm{RV}$, root surface area $\left(\mathrm{mm}^{2} / \mathrm{cm}^{3}\right)=\mathrm{RSA}$, root weighted diameter $(\mathrm{mm})=\mathrm{RWD}$, and productivity $=\mathrm{P}$.

The results reported by Vieira et al., (2010) have most of the Brazilian varieties in a single group with a high initialization value (81.7). Intraspecific hybrids and two Brazilian varieties (Tupi and Icatu Vermelho) were placed in groups with bootstrap values below $50 \%$, which indicates that the observed clustering of varieties in the dendrogram accurately represents the genetic similarity estimates.

By evaluating the scatter plot (Figure 5) of the $\mathrm{CP} 1$ and $\mathrm{CP} 2$ components, the formation of five distinct groups could be observed: group 1 consisted of H-518-3-6-462-M, H-419-3-44-13(C-241) Bordadura, Araponga MG1, H-419-3-3-7-16-11, Mundo Novo Machado, Mundo Novo IAC 376/4, H-516-2-1-1-7-1, Catuaí vermelho IAC 99, Acaiá cerrado MG 1474, Catuaí amarelo IAC 62, Catiguá MG2, and H-419-6-2-4-2-2; group 2 consisted of Mundo Novo IAC 379/19; group 3, H-516-2-1-1-12-1; group 4, H-419-3-4-4-13(C-241) Porte baixo; and group 5 , Catucaí 2 SL.

$\mathrm{RD}$, RSA, and RV were the most important for CP1, even though the values observed in Figure 5 were negative.

Also, as shown in Figure 5, when analyzing the CP2, we found that the largest DBC, SLA, LOB, and DOB were the most important characteristics among the eight evaluated in the experiment.

The components $\mathrm{CP} 1$ and $\mathrm{CP} 3$ (Figure 6) formed five groups: group 1 consisted of Mundo Novo IAC 376/4, H-518-3-6-462-M, H-516-2-1-1-7-1, H-419-3-4-4-13(C-241) Bordadura, Catuaí vermelho IAC 99, Catuaí amarelo IAC 62, Acaiá cerrado MG 1474, H-4193-3-7-16-11, and Mundo Novo IAC 379/19; group 2 consisted of Catiguá MG2; group 3, Catucaí 2 SL; group 4, Araponga MG1; and group 5, H-419-3-4-4-13(C-241) 1-1-12-1.

Genetics and Molecular Research 16 (3): gmr16039794 


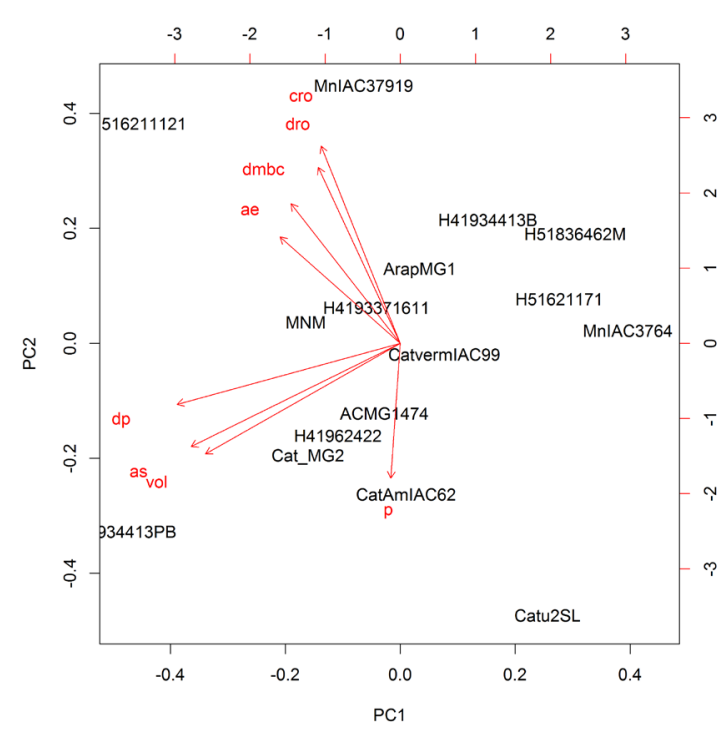

Figure 5. Graph of the CP1 x CP2 scores using 16 accessions of Coffea arabica Morrinhos - Goiás, 2014.

Based on the results presented in the chart of the CP1 x CP3 scores, it is possible to observe that the diameter of the orthotropic branch (DBO), the diameter of the crown base (DCB) and the length of the orthotropic branch (LOB) characteristics are most important for CP1. Root volume (RV), root surface area (RSA) and root weighted diameter (RWD) were the most important for $\mathrm{CP} 3$, despite presenting negative values in the discrimination between $C$. arabica genotypes, as presented in Figure 6. With the use of this information, greater efforts can be concentrated on the evaluation of these characteristics, discarding the evaluation of the others that contributed little to distinguishing the genotypes.

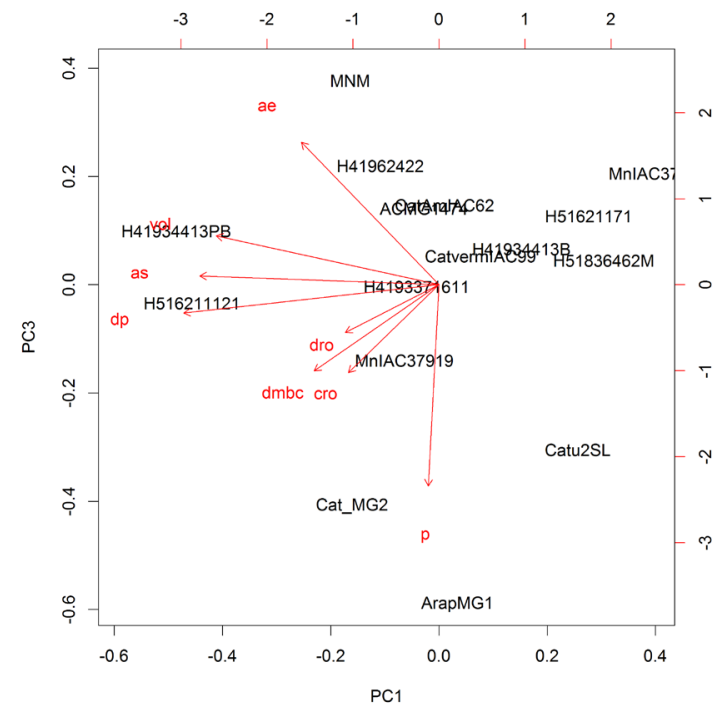

Figure 6. Graph of the CP1 x CP3 scores using 16 accessions of Coffea arabica Morrinhos- Goiás, 2014.

Genetics and Molecular Research 16 (3): gmr16039794 
The graph of CP2 versus CP3 (Figure 7) shows the grouping of the 16 genotypes into six groups: group 1 consisted of Mundo Novo Machado; group 2 consists of H-419-34-4-13(C-241), Catuaí amarelo IAC 62, H-419-6-2-4-2-2, Acaiá cerrado MG 1474, Catuaí vermelho IAC 99, Mundo Novo IAC 376/4, H-516-2-1-1-7-1, H-419-3-3-7-16-11, H-518-3-6462-M, and H-419-3-4-4-13(C-241) Bordadura; group 3, Mundo Novo IAC 379/19 and H-5162-1-1-12-1; group 4, Catucaí 2 SL; group 5, Catiguá MG2; and group 6, Araponga MG1.

The graph of the CP2 2 CP3 scores allowed us to observe that the variables of greater weight for the grouping of the genotypes are DOB, LOB, and DCB for CP2 and RV, RSA, and RWD for CP3. The main components $\mathrm{CP} 2$ and $\mathrm{CP} 3$ effectively differentiate the groupings according to characteristics related to the vegetative and root development of the plants.

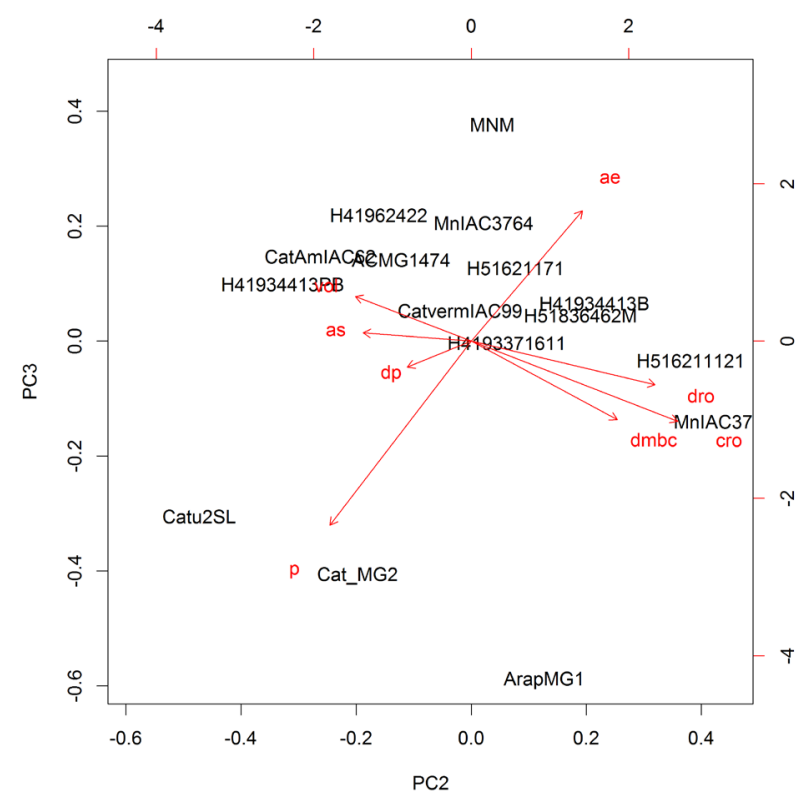

Figure 7. Graph of the CP2 x CP3 scores using 16 accessions of Coffea arabica Morrinhos-Goiás, 2014.

Based on the component scores, it was possible to group the 16 C. arabica genotypes represented in the dendrogram in Figure 8. UPGMA is a more sensitive method for the determination of the number of groups, as it can capture the existence of discrepant accessions more effectively.

The formation of four distinct groups based on these results made it possible to observe that the clustered genotypes form homogeneous groups for the eight characteristics evaluated and that the distinct groups are those among which we find genetic diversity.

Group 1 consisted of H-419-3-4-4-13(C-241); group 2 consisted of Catucaí 2 SL, Catiguá MG2 and Araponga MG1; group 3, Mundo Novo IAC 379/19 and H-516-2-1-1-12-1; and group 4, Mundo Novo IAC 376/4, H-419-3-4-4-13(C-241) Bordadura, H-518-3-6-462-M, H-516-2-1-1-7-1, Mundo Novo Machado, Catuaí vermelho IAC 99, H-419-3-3-7-16-11, Catuaí amarelo IAC 62, Acaiá cerrado MG 1474, and H-419-6-2-4-2-2.

In this case, the genotype H-419-3-4-4-13(C-241) Porte baixo presented the greatest genetic divergence among the 16 genotypes. It was expected that there would be more groups

Genetics and Molecular Research 16 (3): gmr16039794 
and even some of the groups containing many accessions, as only a few of these accessions presented great dissimilarity, as shown in Figure 8. Thus, the genetic divergence of H-419-34-4-13(C-241) Porte baixo can be exploited in breeding programs that target genotypes better adapted to Brazilian cerrado conditions.

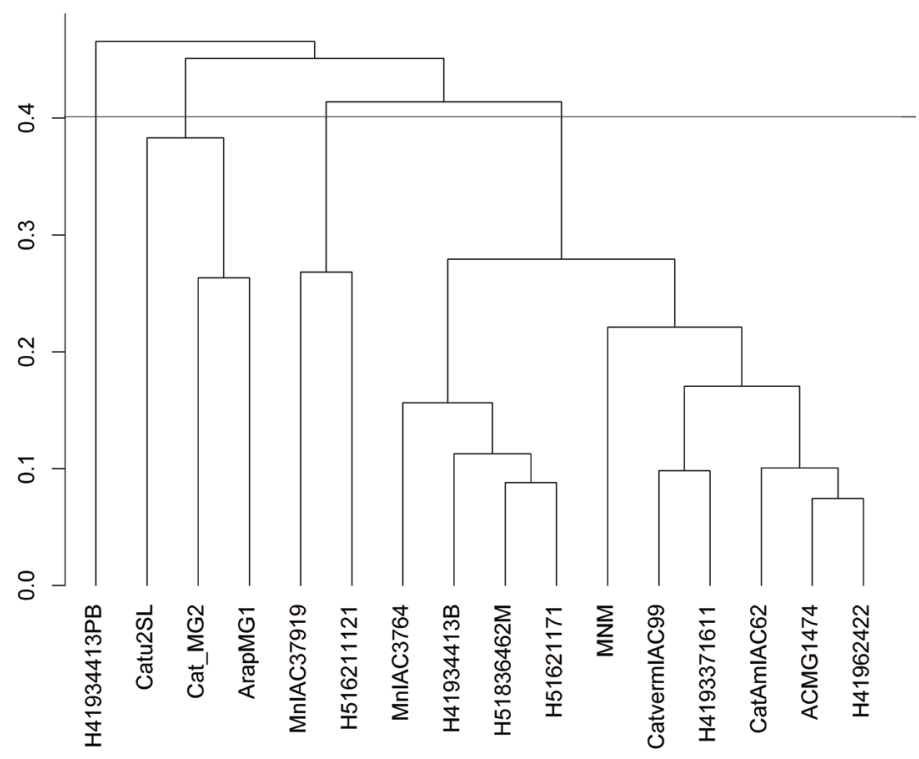

Figure 8. Dendrogram of the main component scores of the 16 genotypes of Coffea arabica, Morrinhos - Goiás, 2014.

\section{CONCLUSIONS}

There is genetic divergence among the 16 genotypes of $C$. arabica evaluated. The genotype H-419-3-4-4-13(C-241) Porte baixo can be considered the most divergent of the 16 genotypes studied, followed by Catucaí $2 \mathrm{SL}$ and Catiguá MG2. It is pertinent to group the formation, based on the UPGMA graphs of the scores of the main components, together with the number of genotypes and characteristics evaluated.

The graphic dispersion obtained from the scores of the main components was effective at identifying the most divergent groups of genotypes.

The multivariate analysis model effectively identified, among all the morphological characteristics studied, that LPB, DOB, the major DCB, RSA, RWD, and RV are the variables of major importance and are considered sufficient for distinguishing the genotypes studied.

\section{Conflicts of interest}

The authors declare no conflict of interest.

\section{ACKNOWLEDGMENTS}

Research supported by CNPq and CAPES.

Genetics and Molecular Research 16 (3): gmr16039794 


\section{REFERENCES}

Alvares RC, Reis EF and Pinto JFN (2012). Genetic divergence in pepper genotypes from southwest Goiás. Cienc. Agrotec. 36: 498-506. https://doi.org/10.1590/S1413-70542012000500002

Botelho CE, Rezende JC De, Carvalho GR, Carvalho AMDe, et al. (2010). Adaptabilidade e estabilidade fenotípica de cultivares de café arábica em minas gerais. Pesqui. Agropecu. Bras. 45: 1404-1411. https://doi.org/10.1590/S0100-204X2010001200010

Covre AM, Partelli FL and Gontijo I (2015). Distribuição do sistema radicular de cafeeiro conilon irrigado e não irrigado. Pesqui. Agropecu. Bras. 50: 1006-1016. https://doi.org/10.1590/S0100-204X2015001100003

CONAB. Companhia Nacional de Abastecimento, acompanhamento da safra brasileira - café, safra 2015/6, primeira estimativa, janeiro/2017, 2017. Available at [http://www.conab.gov.br/olalacms/uploads/ arquivos/17_01_17_14_51_54_boletim_cafe_-_janeiro_de_2017.pdf]. Accessed May 13, 2017.

Cruz CD (2013). GENES - a software package for analysis in experimental statistics and quantitative genetics. Acta Sci. Agron. 35: 271-276. https://doi.org/10.4025/actasciagron.v35i3.21251

Cruz CD, Carneiro PCS and Regazzi AJ (2012). Modelos biométricos aplicados ao melhoramento genético. 3st edn. Federal University of Viçosa, Viçosa.

Cruz CD, Carneiro PCS and Regazzi AJ (2014). Modelos biométricos aplicados ao melhoramento genético. 4 st edn. Federal University of Viçosa, Viçosa.

Cucolotto M, Pípolo VC, Garbuglio DDN, da Silva F, et al. (2007). Genotype x environment interaction in soybean: evaluation through three methodologies. Crop Breed. Appl. Biotechnol. 7: 270-277. https://doi.org/10.12702/1984-7033.v07n03a06

Davis AP, Tosh J, Ruch N and Fay MF (2011). Growing coffee: Psilanthus (Rubiaceae) subsumed on the basis of molecular and morphological data; implications for the size, morphology, distribution and evolutionary history of Coffea. Bot. J. Linn. Soc. 167: 357-377.

Fonseca AFA, Sediyama T, Cruz CD, Sakaiyama NS, et al. (2006). Divergência genética em café conilon. Pesqui. Agropecu. Bras. 41: 599-605. https://doi.org/10.1590/S0100-204X2006000400008

Guedes JM, Vilela DJ, Rezende JC, Silva FL, et al. (2013). Divergência genética entre cafeeiros do germoplasma maragogipe. Bragantia 72: 127-132. https://doi.org/10.1590/S0006-87052013000200003

Jorge LAC and Rodrigues AFO (2008). Safira: Sistema de Análise de Fibras e Raízes. Embrapa instrumentação agropecuária, São Carlos, 1-20. Avaliable at [https://www.infoteca.cnptia.embrapa.br/bitstream/doc/31890/1/BPD242008.pdf].

Mojena R (1977). Hierarquical grouping methods and stopping rules: an evaluation. Comput. J. 20: 359-363. https://doi. org/10.1093/comjnl/20.4.359

Martins MQ, Rodrigues WP, Fortunato AS, Leitão AE, et al. (2016). Protective response mechanisms to heat stress in interaction with high [CO2] conditions in Coffea spp. Front. Plant Sci. 7: 947. https://doi.org/10.3389/fpls.2016.00947

Oliveira ACB, Pereira AA, Silva FL, Rezende JC, et al. (2011). Prediction of genetic gains from selection in arabica. Crop Breed. Appl. Biotechnol. 11: 106-113. https://doi.org/10.1590/S1984-70332011000200002

Partelli FL, Vieira HD, Santiago AR, Barroso DC, et al. (2006). Produção e desenvolvimento radicular de plantas de café 'conilon' propagadas por sementes e por estacas. Pesqui. Agropecu. Bras. 41: 949-954. https://doi.org/10.1590/ $\underline{\text { S0100-204X2006000600008 }}$

Partelli FL, Covre AM, Oliveira MG, Alexandre RS, et al. (2014). Root system distribution and yield of 'conilon' coffee propagated by seeds or cuttings. Pesqui. Agropecu. Bras. 49: 349-355. https://doi.org/10.1590/S0100$\underline{204 X 2014000500004}$

Petek MR, Sera T and Fonseca ICB (2008). Predição de valores genéticos aditivos na seleção visando obter cultivares de café mais resistentes à ferrugem. Bragantia 67: 133-140. https://doi.org/10.1590/S0006-87052008000100016

Rodrigues WP, Vieira HD, Teodoro PE, Partelli FL, et al. (2016). Assessment of genetic divergence among coffee genotypes by Ward-MLM procedure in association with mixed models. Genet. Mol. Res. 15: 1-7. https://doi. org $/ 10.4238 / \mathrm{gmr} .15027889$

Sera T (2001). Coffee genetic breeding at iapar. Crop Breed. Appl. Biotechnol. 1: 179-200. https://doi.org/10.13082/19847033.v01n02a08

Silva FL, Bafa DCF, Oliveira ACB, Pereira AA, et al. (2013). Integração de dados quantitativos e multicategóricos na determinação da divergência genética entre acessos de cafeeiro. Bragantia 72: 224-229. https://doi.org/10.1590/ brag.2013.039

Teixeira AL, Gonçalves FMA, Rezende JC, Rocha RB, et al. (2013). Análise de componentes principais em caracteres morfológicas de café arábica em estádio juvenil. Coffee Sci. 8: 205-210.

Vieira ESN, Pinho EV de R, Carvalho MGG, Esselink DG, et al. (2010). Development of microsatellite markers for identifying Brazilian Coffea arabica varieties. Genet. Mol. Biol. 33: 507-514. https://doi.org/10.1590/S1415$\underline{47572010005000055}$

Genetics and Molecular Research 16 (3): gmr16039794 